\title{
Santé Publique
}

2015/1 (Vol. 27)

- Pages : 154

- Éditeur : $\underline{\text { S.F.S.P }}$

\section{Comment optimiser l'efficience de l'aide internationale, dans le domaine de la santé, en République Démocratique du Congo}

par Joseph Manzambi Kuwekita

et Olivier Bruyère

et Michèle Guillaume

et Christiane Gosset

et Jean-Yves Reginster

Pages 129 - 134

Résumé

Français

L'analyse des comptes nationaux de santé de la République Démocratique du Congo $(R D C)$ montre le rôle essentiel joué par l'aide internationale, en particulier dans le financement des hôpitaux généraux de référence, des hôpitaux de prise en charge du sida, de l'administration des zones de santé et du financement des prestataires de soins préventifs.

Il semble possible, par des changements ciblés, évoqués dans cet article, d'optimaliser le bénéfice retiré par la population congolaise de l'aide internationale, en particulier, dans le domaine des maladies prioritaires (paludisme, sida, tuberculose) ainsi que dans la lutte contre la malnutrition. Les recommandations portent sur la mise en place de procédures de contrôle de la sécurité de la chaîne alimentaire, sur le changement des comportements de la population vis-à-vis de la prévention des maladies prioritaires mais également sur une refonte globale de l'organisation des soins de santé. Une modification drastique de la structure de distribution des médicaments et l'arrêt de la rétrocession, à la hiérarchie, d'une part des recettes des structures de santé devraient permettre de libérer des moyens importants pour lutter contre les maladies prioritaires.

Une meilleure collaboration entre le Ministère de l'Enseignement supérieur et le Ministère de la Santé, aboutissant à une refonte de la formation des personnels de santé, avec une responsabilisation progressive des agents en place, semble un prérequis. Il convient d'impliquer des organisations non-gouvernementales 
crédibles dans un processus d'évaluation des structures sanitaires de la RDC. Enfin, dans un souci d'équité tenant compte de la pauvreté des ménages, des actions telles que la mise en place d'une assurance-santé, le recours aux médicaments génériques et la généralisation des micro-crédits peuvent également être considérés.

Mots-clés

- $\quad$ administration des services de santé

- coopération internationale

- $\quad$ financement des soins de santé

- $\quad$ prestations des soins de santé

- Congo

\section{English}

How to optimize the efficiency of international sanitary aid in the Democratic Republic of CongoAnalysis of national health insurance accounts in the Democratic Republic of Congo (DRC) clearly shows the importance of international sanitary aid, particularly for the funding of general referral hospitals, the management of inpatients with AIDS, administration of health zones and funding of preventive care providers.

It The targeted changes described in this article could possibly optimize the efficiency of international aid for the DRC population, mainly for disorders considered to be a health care priority (i.e. malaria, AIDS, tuberculosis) as well as in the fight against malnutrition.

Recommendations target the implementation of procedures for control of food chain security, changes in lifestyle and dietary habits of the population but also comprise extensive restructuring of the health care administration. A dramatic change of the structure in charge of drug distribution as well as eradication of the transfer of part of public health structure income to public health administrative personnel could result in the allocation of significant funds to the fight against the most important diseases.

Better collaboration between the various departments in charge of health care professional training, together with enhanced responsibility of health care personnel is essential.

Independent and respected non-governmental organizations should be involved in an audit process, targeting all aspects of the current DRC health system.

Eventually, in an equal opportunity perspective, taking into consideration the very high degree of poverty of DRC inhabitants, implementation of health insurance programmes, use of generic drugs and generalization of micro-credit initiatives should also be implemented.

\section{Keywords}

- delivery of health care

- $\quad$ health care financing

- $\quad$ health services administration 


\section{Plan de l'article}

1. Introduction

2. Coût des maladies prioritaires

3. Rôle de l'aide internationale

4. Réflexions pour l'optimisation de l'utilisation de l'aide internationale

5. Conclusion

\section{Pour citer cet article}

Manzambi Kuwekita Joseph, Bruyère Olivier, Guillaume Michèle, Gosset Christiane, Reginster Jean-Yves, « Comment optimiser l'efficience de l'aide internationale, dans le domaine de la santé, en République Démocratique du Congo », Santé Publique 1/2015 (Vol. 27) , p. 129-134

URL : www.cairn.info/revue-sante-publique-2015-1-page-129.htm. 